\title{
A study of contextual precursors of burnout among EFL teachers
}

Rostami, Soroor

Imam Reza International University, Iran (rostami.soroor@yahoo.com)

Ghanizadeh, Afsaneh $\bowtie$

Imam Reza International University, Iran (afsanehghanizadeh@gmail.com)

Ghapanchi, Zargham

Ferdowsi University of Mashhad, Iran (zghapanchi@gmail.com)

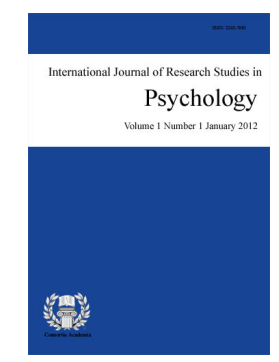

ISSN: 2243-7681 Online ISSN: 2243-769X

OPEN ACCESS

\section{Abstract}

Teachers' burnout has been recognized as a serious occupational problem in school systems worldwide. The primary aim of the present study is to delve into the context laden factors affecting teacher burnout. In particular, it sought to investigate EFL teachers' burnout across two strikingly different contexts of EFL learning in Iran, i.e., high schools and language institutes. Besides, it aimed at examining the role of gender, age, and years of teaching experience in teacher burnout. A total of 120 teachers, 60 secondary school teachers and 60 institute EFL teachers completed the Maslach burnout inventory (MBI-ES) questionnaire. The results demonstrated that teachers in Official context reported significantly higher levels of burnout than teachers in Non-official context. In terms of age and years of teaching experience, the results of the study showed that teacher burnout and its subscales positively and significantly correlated with both teachers' age and teachers' years of teaching experience in both contexts. Furthermore, regarding gender differences in teacher burnout, the present study found no significant difference in burnout level in both contexts. Finally, the results were discussed in the context of language learning and some suggestions were presented to administrators for using a suppressive strategy to prognosticate teacher burnout.

Keywords: burnout; gender; age; years of teaching experience; official context; non-official context 


\section{A study of contextual precursors of burnout among EFL teachers}

\section{Introduction}

Burnout is a syndrome that afflicts people who work in "helping professions" or other client-centered fields (Schwab, 1986). One of the professions characterized by high levels of burnout and emotional exhaustion is teaching (Hakanen, Bakker, \& Schaufeli, 2006; Maslach, Schaufeli, \& Leiter, 2001). In the field of education, McGuire (1979) first warned that public school teacher occupations were being significantly affected by burnout. Teacher burnout has been defined in a variety of ways but probably the most widely-used definition is the one proposed by Maslach (1982) describing it as: "a syndrome of emotional exhaustion, depersonalization, and reduced personal accomplishment" (p. 3). These three dimensions of burnout are generally used as the basis for any discussion on teacher burnout, along with the educator version of the burnout inventory (MBI) as the standard measurement tool (Maslach, Jackson, \& Leiter, 1996). First, the facet of emotional exhaustion occurs when teachers feel their emotional resources being depleted and overextended by contact with other people, particularly their students. Depersonalization occurs when teachers develop impersonal and even dehumanized perception of others. Reduced personal accomplishment refers to a decline in professional competence and effectiveness (Bibou-Nakou, Stogiannidou, \& Kiosseoglou, 1999, as cited in Ghanizadeh, 2013).

Factors that influence teacher burnout include intrapersonal, interpersonal, social, and organizational variables (Burke \& Greenglass, 1995; Papathanasiou \& Hirsch, 1997). From an intrapersonal perspective, there is an anecdotal evidence that teacher burnout is closely connected to beliefs and perceptions (Bibou-Nakou et al., 1999, as cited in Ghanizadeh \& Ghonsooly, 2014, p. 148).Six major influences on burnout were outlined by Maslach and Leiter (1997, 1999): (1) workload and its intensity, time demands, and complexity; (2) lack of control over establishing and following day-to-day priorities; (3) insufficient reward and the accompanying feelings of continually having to do more for less; (4) the feeling of community, in which relationships become impersonal and teamwork is undermined; (5) the absence of fairness, in which trust, openness, and respect are not present; and (6) conflicting values, in which choices that are made by management often conflict with their mission and core values, and we don't always practice what we preach.

In an attempt to present possible sources of teacher burnout, Chang (2009) reviewed the existing literature on teacher burnout and concluded that there are three potential sources as: individual, organizational, and transactional sources. Studies identifying individual factors as the main sources of burnout provided the answers to questions like "who experiences burnout?", while studies identifying sources of burnout as social and organizational factors answer to questions like "what makes teachers burnout?". Furthermore studies that examined transactional factors as the main sources of burnout answer to questions like "who experiences higher levels of burnout in which situations".

\subsection{Individual factors}

Demographic variables or personality variables such as gender, age, years of teaching experience, personality, etc. are called individual factors (Chang, 2009). A number of individual characteristics associated with teacher burnout have been studied within the literature. Gender is one such factor which indicated mixed results. For instance, some studies did not find any significant difference in teacher burnout in terms of gender (e.g., Farber1984; Kahn, Schneider, Jenkins-Henkelman, \& Moyle, 2006). On the other hand, in different examinations done by Anderson and Iwanicki (1984); Burke and Greenglass (1989); Byrne (1991); Greenglass and Burke (1990); Ogus, Greenglass, and Burke, (1990); Russell, Altmaier, and Van Velzen, (1987); Schwab and Iwanicki, (1982); Schwab, Jackson, and Schuler, (1986) (as cited in Ghanizadeh, 2013) the aspect of depersonalization is proved to be significantly in higher level for males rather than for females (these researches were done for elementary and high school teachers). 
In terms of age which can be regarded as an outstanding and differentiating variable, findings are not very consistent. Some studies demonstrated a significant negative correlation with age and some aspects of burnout (Sarros \& Sarros, 1992; Whitehead, Ryba, \& O'Driscoll, 2000), others indicated significant positive correlations (Evers, Brouwers, \& Tomic, 2002; Jacobsson, Pousette, \& Thylefors, 2001), and some have found no evidence to consider age as a predictor of teacher burnout (Brissie, Hoover-Dempsey, \& Bassler, 1988; Hastings \& Bham, 2003; Rashidzadeh, 2002; Rosenblatt, 2001; Zabel \& Zabel, 2001).

Another Individual factor studied in the present study is years of teaching experience. Some studies indicated that younger teachers are the most susceptible to burnout. Byrne (1998) proposed that the feeling burnout could be reduced as a result of professional maturity and that explains higher score on MBI for teachers of 0-10 years' experience compared to those having more than 10 years' experience. Moreover, Konert (1997) reported significant difference between more experienced teachers and less experienced teachers by suggesting that more experienced teachers could have developed better coping skills with their students than less experienced teachers (Duatepe \& Akkus-Cikla, 2004). There were also some inconsistent findings relating to relationship between teacher burnout and years of teaching experience (Bayram, Gürsakal, \& Bilgel, 2010; Egyed, \& Short, 2006; Jackson, Barnett, Stajich, \& Murphy, 1993; Sunbul, 2003). Sunbul (2003) stated that educators with more years of experience have higher levels of emotional exhaustion and depersonalization. Ozdemir (2007) solved this paradox suggesting that burnout appears in early and late in the career of teachers. Mid-career educators have the stamina and skills to cope up and show less burnout compared to new educators or educators of more than 24 years.

In Iranian context, Akbari and Karimiallvar (2007) explored Iranian language educators' burnout in relation to demographics, personality structure, and self-efficacy. The results revealed a significant effect of introvert, intuitive, and feeling dimensions of personality on burnout but no effect of extrovert, sensing, and thinking dimensions. No significant difference was found between the burnout means of male and female teachers while a significant difference was found among teachers with different years of teaching experience. Another study conducted by Vaezi and Fallah (2011) investigating the relationship between Iranian EFL teachers' burnout, emotional intelligence, age and teaching experience indicated there was a significant negative correlations between emotional intelligence and burnout; and between burnout, teaching experience and age. In a recent study, Bayani, Bagheri, and Bayani (2013) investigated the relationship between gender, age, years of teaching experience, and burnout in teachers of secondary school. No significant differences were found in burnout, emotional exhaustion, depersonalization, and reduced personal accomplishment in respective of the age, years of teaching experience. However, male teachers tended to show larger burnout, emotional exhaustion, and depersonalization than the female teachers. Moreover, TabatabaeeYazdi, Motallebzadeh, and Ashraf (2013) explored the correlation between self-efficacy of Iranian English EFL teachers and their reports of burnout. The finding indicated that the participants' self-efficacy has a reverse relationship with their burnout. In addition, a significant relationship was observed between teachers' age, gender, years of experiences and reports of burnout. In a recent study, Ghanizadeh and Ghonsooly (2014) examined the role of teacher attributions in teacher burnout and found that teacher burnout is associated with external and uncontrollable attributions.

\subsection{Organizational factors}

Organizational factors include class size, work demands, inadequate salary, organizational rigidity, teacher preparation, etc. Studies identifying organizational factors as sources of burnout explored in what kinds of institutional contexts do teachers become burned out (Chang, 2009, as cited in Ghanizadeh, 2013). Factors believed to contribute to teacher burnout include "lack of social support from and administrators (Brissie, Hoover-Dempsey, \& Bassler, 1988;Burke \& Greenglass, 1993; Maslach, Schaufeli, \& Leiter, 2001), lower school social economic status, organizational rigidity (Brissie, Hoover-Dempsey, \& Bassler, 1988), excessive work demands, inadequate salary or resources (Milstein, Golaszewski, \& Duquette, 1984), insufficient teacher preparation or training in dealing with student discipline problems (Farber, 1984; Gold \& Bachelor, 1988), lack of teacher participation in school decision making (Brissie, Hoover-Dempsey, \& Bassler, 1988), and other 
Rostami, S., Ghanizadeh, A., \& Ghapanchi, Z.

physical variables, such as overcrowded classrooms, poor workplaces, and poor work conditions" (Chang, 2009, pp. 200-201).

Despite the bulk of research examining organizational factors as sources of burnout, a cross-comparison of these sources in two strikingly different contexts (Official and Non-official) remained an unchartered territory awaiting further research among EFL teachers. Secondary schools and language institutes are two dramatically different contexts of EFL learning in Iran. In Official context of secondary schools, English is a required course. Teacher has the central role and learners are considered as receivers of information, listeners, and imitators. As Keihaniyan (2011, p. 598) stated "in such traditional language learning contexts, learners do not have any role in teaching process and they just repeat new structures and new words". In other words, the common educational system in Iranian schools relies on a traditional teaching approach (Rostami, Akbari, \& Ghanizadeh, 2015). In this traditional mode of teaching, teachers tend to impose rigid and less flexible ways of managing students and their concerns. In contrast, most of Non-official contexts of language learning are typically conducted based on modern approaches of language learning. In classes conducted by these teaching methods, teachers and learners work together, and the boundaries between teachers and learners are not as formal and inflexible as classes conducted by traditional-oriented approaches.

Taken together, the role of the constructs identified in the preceding discussion - gender, age, years of teaching experience, school and legislative factors and their relationship with teacher burnout,-in effective teaching has conclusively been demonstrated by education researchers. The present research aimed at examining these constructs within a single framework with a specific focus on the role of contextual factors in teacher burnout.

\subsection{Purpose of study}

The main purpose of this study is to investigate the role of school and legislative factors in teacher burnout. $\mathrm{T}$ also seeks to examine the impact of gender, age, and years of teaching experience on burnout depletion., and Viewed from a broader perspective, it seeks to examine and interpret the hypothesized relationships among several individual and organizational factors with teacher burnout, within a single framework in two contexts (Official and Non-official) which differ in various respects such as heterogeneity of learners, teaching approaches and methods, teachers and learner roles, and number of students. This study addresses the following questions:

$>$ Q1. Is there any significant difference between burnout level of EFL teachers across Official and Non-official contexts?

$>\quad$ Q2. Is there any relationship between EFL teachers' burnout and their age in each context?

$>$ Q3. Is there any relationship between EFL teachers' burnout and amount of teaching experience in each context?

$>\quad$ Q4. Is there any relationship between EFL teachers' burnout and their gender in each context?

\section{Method}

\subsection{Participants}

Two different samples comprised the participants of the present study. The first sample was selected from EFL teachers teaching at secondary school EFL teachers and the second sample consisted of EFL teachers teaching at language institutes. The profile of participants of each setting is as follows:

Setting 1: The first group of participants comprised $60 \mathrm{EFL}$ teachers teaching at different secondary schools 
A study of contextual precursors of burnout among EFL teachers

(Official context). They were 30 females and 30 males whose age varied from 26 to $54(M=30, S D=8.35)$ with 4-26 years of teaching experience $(M=16.56, S D=8.49)$.

Setting 2: The second group of participants comprised 60 institute EFL teachers (Non-official context). They were 37 females and 23 males whose age varied from 20 to $42(M=27.68, S D=6.14)$ with 1-23 years of teaching experience $(M=7.48, S D=5.19)$.

\subsection{Instrument}

The current study employed the educator version of the Maslach burnout inventory (MBI-ES) developed by Maslach, Jackson, and Leiter (1996) to measure teacher burnout. The scale comprises 22 self-report items measured on three subscales. Nine items measure emotional exhaustion (e.g., "I feel used up at the end of the day"), five items measure depersonalization (e.g., "I worry that this job is hardening me emotionally"), and eight items measure personal accomplishment (e.g., "I have accomplished many worthwhile things in this job").The frequency of burnout symptoms is measured on a seven-point rating scale, ranging from never (0) to every day (6). Higher emotional exhaustion and desensitization sub-dimensions and lower personal accomplishment sub-dimensions cause high burnout status. The inventory enjoys high reliability and validity indices (Hastings \& Bham, 2003). Table 1 displays the reliability indices (measured via Cronbach's alpha) of the questionnaire in the original study (Maslach, Jackson, \& Leiter, 1996) as well as in the two contexts of the present study, i.e., high schools (Setting 1) and language institutes (Setting 2), respectively.

\section{Table 1}

The Reliability Indices of the Scale

\begin{tabular}{lcccc}
\hline \multicolumn{1}{c}{ Subscale } & Item No. & $\begin{array}{c}\text { Reliability in } \\
\text { original study }\end{array}$ & $\begin{array}{c}\text { Reliability in } \\
\text { Setting 1 }\end{array}$ & $\begin{array}{c}\text { Reliability in } \\
\text { Setting 2 }\end{array}$ \\
\hline Emotional exhaustion & $\begin{array}{l}1,4,9,10,15, \\
16,18,20,22\end{array}$ & 0.76 & 0.98 & 0.98 \\
Reduced personal accomplishment & $\begin{array}{l}3,6,7,12,13, \\
17,19,21\end{array}$ & 0.73 & 0.97 & 0.98 \\
Depersonalization & $2,5,8,11,14$ & 0.63 & 0.83 & 0.91 \\
\hline
\end{tabular}

\subsection{Procedure}

The first part of study was undertaken in secondary schools (several guidance and high schools, e.g. Amir Kabir, BaqerolOlum, EmamHossein, Emam Reza, Esteqlal, Ferdowsi, Mehregan, Najmeh, Saadi, and ShahidJabbarian) in Mashhad, between April and May 2014. Their selection was based on convenience sampling and the participation was entirely voluntary. To achieve reliable data, the researchers explained the purpose of completing the questionnaire and asked them not to write a name on them. All the data were analyzed with SPSS 20. The second part of the study was undertaken in several private Language Institutes (e.g. Daneshju, EmamHossein, Hafez, Iran Language Institute, Kish Air, Mehran, NureDanesh, Safir, and Shokuh) in Mashhad between May and July 2014. An identical data collection procedure was used.

\section{Results}

SPSS 20 (Statistical Package for Social Sciences) was used to analyze descriptive statistics, Pearson correlation formula, and $t$-test. To answer the first question in order to see whether teacher burnout differs significantly in Official and Non-official contexts, an independent-samples $t$-test was used. Levene's test indicated heterogeneity of variance on three of the measures, namely, reduced personal accomplishment, depersonalization, and burnout. Therefore, based on the Levene's test, appropriate degrees of freedom and $t$ values were selected. 
Rostami, S., Ghanizadeh, A., \& Ghapanchi, Z.

Table 2

Independent T-Test displaying the results of teacher burnout differs significantly in setting 1 and 2

\begin{tabular}{lccccc}
\hline \multirow{2}{*}{ Subscales } & \multicolumn{5}{c}{ t-test for Equality of Means } \\
\cline { 2 - 6 } & \multirow{2}{*}{$t$} & $d f$ & Sig. (2-tailed) & $\begin{array}{c}\text { Mean } \\
\text { Difference }\end{array}$ & $\begin{array}{c}\text { Std. Error } \\
\text { Difference }\end{array}$ \\
\hline Emotional exhaustion & 3.90 & 118 & .00 & 9.20 & 2.35 \\
Reduced personal accomplishment & 4.75 & 105.49 & .00 & 10.40 & 2.18 \\
Depersonalization & 4.22 & 110.42 & .00 & 2.90 & .68 \\
Burnout & 4.76 & 111.83 & .00 & 22.50 & 4.72 \\
\hline
\end{tabular}

As indicated in Table 2 there is a statistically significant difference between all the variables. The highest difference was observed in burnout $(t=4.76, P<0.05)$ and the lowest difference was observed in emotional exhaustion $(t=3.90, P<0.05)$. It means that teachers in Official context (setting 1$)$ reported significantly higher levels of burnout $(M=80.81, S D=2.26)$ than teachers in Non-official context (setting 2$)(M=58.31, S D=2.87)$. To answer the second and third research questions, Pearson Coefficient correlation was conducted using SPSS 20. The mean, standard deviation, and correlation coefficient between subscales of teacher burnout, age and teaching experience for setting 1 (Official context) and setting 2 (Non-official context) are presented in Table 3 and Table 4 , respectively.

\section{Table 3}

Results of correlation between subscales of teacher burnout, age and teaching experience in setting 1

\begin{tabular}{lccc}
\multicolumn{1}{c}{ Subscales } & $M(S D)$ & age & years of experience \\
\hline Emotional exhaustion & $33.08(1.18)$ & $0.78^{*}$ & $0.81^{*}$ \\
Reduced personal accomplishment & $34.43(9.69)$ & $0.80^{*}$ & $0.81^{*}$ \\
Depersonalization & $13.30(3.23)$ & $0.37^{*}$ & $0.38^{*}$ \\
Burnout & $80.81(2.26)$ & $0.81^{*}$ & $0.82^{*}$ \\
\hline
\end{tabular}

Note. $*$ Shows the existence of the significant relationship at the level of 0.05

As demonstrated by the table, teacher burnout and its subscales positively and significantly correlated with both teachers' age and teachers' years of teaching experience. The highest correlation was observed between total burnout and teaching experience $(r=0.82, P<0.05)$. The lowest correlations were observed between depersonalization and age $(r=0.37, P<0.05)$, and depersonalization and experience $(r=0.38, P<0.05)$ respectively.

\section{Table 4}

Results of correlation between subscales of teacher burnout, age and teaching experience in setting 2

\begin{tabular}{lccc}
\hline \multicolumn{1}{c}{ Subscales } & $M(S D)$ & age & years of experience \\
\hline Emotional exhaustion & $23.88(1.38)$ & $0.82^{*}$ & $0.81^{*}$ \\
Reduced personal accomplishment & $24.03(1.38)$ & $0.79^{*}$ & $0.79^{*}$ \\
Depersonalization & $10.40(4.22)$ & $0.17^{*}$ & $0.17^{*}$ \\
Burnout & $58.31(2.87)$ & $0.80^{*}$ & $0.80^{*}$ \\
\hline
\end{tabular}

Note. ${ }^{*}$ Shows the existence of the significant relationship at the level of 0.05

As was indicated in the table, teacher burnout and its subscales positively and significantly correlated with both teachers' age and years of teaching experience. The highest correlation was observed between emotional exhaustion and age $(r=0.82, P<0.05)$. The lowest correlations were observed between depersonalization and age $(r=0.17, \quad P<0.05)$, and depersonalization and teaching experience $(r=0.17, P<0.05)$ respectively. A cross-comparison of the correlations between age, experience, and burnout in the two settings indicates that the magnitudes of the correlations are quite identical. The only noticeable incompatibility is observed in the correlation between depersonalization and age as well as experience which is about half in setting 2 .

To answer the last research question aiming at examining whether teacher burnout differs significantly between genders in each context an independent-samples $t$ test was used for each setting. Table 5 and 6 display the results of $t$ - tests in official and non-official settings, respectively. Levene's test indicated heterogeneity of 
A study of contextual precursors of burnout among EFL teachers

variance on reduced personal accomplishment for Official context. As indicated in table 5, there is no significant difference between gender, burnout, and its subscales.

\section{Table 5}

Independent T-Test displaying the results of gender differences in setting 1

\begin{tabular}{lccccc}
\hline \multirow{2}{*}{ Subscales } & \multicolumn{5}{c}{ t-test for Equality of Means } \\
\cline { 2 - 6 } & \multirow{2}{*}{$t$} & $d f$ & Sig. (2-tailed) & $\begin{array}{c}\text { Mean } \\
\text { Difference }\end{array}$ & $\begin{array}{c}\text { Std. Error } \\
\text { Difference }\end{array}$ \\
\hline Emotional exhaustion & -.21 & 57 & .82 & -.68 & 3.13 \\
Reduced personal accomplishment & -1.06 & 54.88 & .29 & -2.63 & 2.47 \\
Depersonalization & .53 & 58 & .59 & .44 & .84 \\
Burnout & -.48 & 58 & .63 & -2.82 & 5.88 \\
\hline
\end{tabular}

Levene's test indicated heterogeneity of variance on three of the measures, namely, emotional exhaustion, depersonalization, and burnout for Non-official context. As indicated in the Table 6 there are no significant differences between gender and burnout $(t=-.92, p<0.05)$, as well as gender and emotional exhaustion $(t=.-1.02$, $p<0.05)$ and reduced personal accomplishment $(t=-1.67, p<0.05)$. The only significant difference is observed between depersonalization and gender $(t=3.10, p<0.05)$. It implies that female teachers are more prone to depersonalization than their male counterparts in setting 2 .

Table 6

Independent T-Test displaying the results of gender differences in setting 2

\begin{tabular}{lccccc}
\hline \multirow{2}{*}{ Subscales } & \multicolumn{5}{c}{ t-test for Equality of Means } \\
\cline { 2 - 6 } & \multirow{2}{*}{$t$} & $d f$ & Sig. (2-tailed) & $\begin{array}{c}\text { Mean } \\
\text { Difference }\end{array}$ & $\begin{array}{c}\text { Std. Error } \\
\text { Difference }\end{array}$ \\
\hline Emotional exhaustion & -1.02 & 32.31 & .31 & -4.20 & 4.09 \\
Reduced personal accomplishment & -1.67 & 58 & .10 & -6.07 & 3.63 \\
Depersonalization & 3.10 & 57.23 & .00 & 2.90 & .93 \\
Burnout & -.92 & 39.62 & .36 & -7.38 & 8.02 \\
\hline
\end{tabular}

\section{Discussion}

As stated before, the present study sought to examine primarily the role of contextual factors in burnout. In particular, it explored the manifestations of these contextual factors in two different milieus of language learning, i.e., public secondary schools and private language schools. As discussed earlier, these contextual factors are the reflections of the differences residing in these two educational settings. Furthermore, in this study, we investigated the role of gender, age, and years of teaching experience in teacher burnout. The results demonstrated that teachers in Official context reported significantly higher levels of burnout than their counterparts in Non-official context. This finding can be explained in the light of striking disparities inherent in these two settings. English classes in official high schools in Iran are usually crowded ones with heterogeneous language learners. The teachers of these classes inevitably spend disproportionate amount of time and energy in creating classroom disciplinary climate.

Given the obvious potential of classroom behavior problems pertained to these tight environments, it is reasonable to expect that teachers of these classes come to this realization that teaching is beyond method and strategy and failure to address any behavior that interferes with students' learning or their ability to operate effectively is a more challenging aspect of teaching practices. What's more, the executed curriculum of English classes at Iranian high schools is compatible with the traditional methods such as grammar-translation and reading approaches. The teacher in such contexts primarily serves as the authority that manipulates students and controls the direction and pace of learning. In these teacher-dominated classes, interactions between teacher and students and interactions among students are frequently deemphasized. This may adequately explain why in the present study teachers of official settings exhibited higher levels of emotional exhaustion, depersonalization, and 
reduced accomplishment. Besides, the teachers of the official Iranian high schools are usually employed on a permanent contract and on a full-time basis. Thus, the stability of employment with hardly any regular inspection or observation by administration authorities or parents seems to undermine teachers' incentive to implement, innovative and efficient techniques and strategies. This in turn may account for high level of burnout in Official context in Iran.

Moazzam and Jodai (2014) found that there was a significant difference between the characteristics of high school teachers and those of language institute teachers. Their results indicated that institute teachers significantly outperformed high school teachers in 14 out of 46 items of the questionnaire including 'understanding spoken English well", "being available for the students", "Being punctual", "being open to criticism", "being polite and respecting the personality of students", "listening to student opinions and letting them express themselves", and "showing interests in students and their learning". Moreover, Ghaffarzadeh Hassankiadeh (2013) stated that school teachers are expected to increase learners' ability in structural recognition and memorizing skills. They are not free to choose the procedures and text-books, too. On the other hand, institute teachers can select the institute, text-books or even the learners that they desire to teach. They can teach the ones that cover their beliefs as much as possible. There is no powerful authority which may limit teachers and learners in a way that may hurt teaching/learning processes.

In terms of age and years of teaching experience, the results of the study showed that teacher burnout and its subscales positively and significantly correlated with both teachers' age and teachers' years of teaching experience in both contexts. In other words, as teachers become more experienced and with the passage of time, they are more prone to burned out syndrome. This is in line with to the burnout conceptualization as "a state of physical, emotional and mental exhaustion caused by long-term involvement in situations that are emotionally demanding (Harrison, 1999, p. 25). The results are inconsistent with the findings reported by Duatepe and Akkuş-Çıkla (2004) and Bayani, Bagheri, and Bayani (2013). Duatepe and Akkuş-Çıkla (2004) found that burnout of teachers with 0-10 years' experience is higher than the burnout of the teachers with more than 10 years' experience. Moreover, the results of the study conducted by Bayani, Bagheri, and Bayani (2013) in Iran in a formal context revealed that age differences and years of teaching experience do not lead to differing levels of teacher burnout.

Regarding gender differences in teacher burnout, the present study found no significant difference in burnout level in both contexts. The only significant difference is observed between depersonalization and gender in setting 2. It implies that female teachers are more prone to depersonalization than their male counterparts in Non-official context. These findings are consistent with studies conducted by Lau, Yuen, and Chan (2005) and Toker (2011). In a study conducted by Toker (2011) in Turkey, the results indicated that there was no significant difference in level of burnout among male and female teachers. Lau, Yuen, and Chan (2005) reported that female teachers reported higher burnout in depersonalization. These findings, nevertheless, contradict Greenglass and Burke (1988), Duatepe and Akkuş-Çıkla (2004) and Bayani, Bagheri, and Bayani (2013) studies. Duatepe and Akkuş-Çıkla (2004) concluded that the burnout of male teachers is higher than the burnout of female teachers. Greenglass and Burke (1988) and Bayani, Bagheri, and Bayani (2013) also found that men teachers were significantly higher than women in depersonalization.

\subsection{Implications}

Based on the results of this study, it appears that burnout depletion among teachers deserves specific attention. Accordingly, educational policy makers are recommended to present intervention programs making teachers familiarized with the syndrome and helping them mitigate burnout and stress. Such programs can be differentiated based on the orientation and intention of the designed treatment: (a) direct action programs dealing directly with the causes of burnout, and (b) palliatives programs involving indirect treatment of burnout, focusing on techniques for alleviating tension or fatigue. These intervention programs should take into account the potential causes responsible for burnout origination and development. 
A study of contextual precursors of burnout among EFL teachers

Previous research has indicated that emotional exhaustion is the prime predictor of teacher burnout and is directly linked to negative exchanges with students and teachers' personal experiences and characteristic (Ghanizadeh \& Jahedizadeh, 2015). Teacher education programs, thus, are recommended to structure regulation strategies programs with a specific focus on the emotional side of teachers' profession. Diefendorff, Richard, and Yang (2008) put forward the following emotion regulation strategies which might help teachers diminish burnout syndrome:

1. Seek out individuals, who make you feel good;

2. Keep yourself busy working on other things;

3. Do something enjoyable to improve your mood;

4. Try to solve the problem;

5. Find humor in the situation;

6. Think about how the other person feels;

7. Consider how things could be worse;

8. Pretend you are in a good mood;

9. Turn your attention to something that doesn't bother you, and

10. Remind yourself that you cannot control everything.

At the organizational levels, the strategies might include, reducing degree of polarization in the classroom; reducing number of pupils per class, and changing teacher's work plan or teaching plan. Additionally, treatment of symptoms of stress for the organizational level could be creating a supportive atmosphere in the school; opening channels of communication; involvement in decision making, and developing a positive and open organizational climate (Ghanizadeh \& Jahedizadeh, 2015).

\section{References}

Akbari, R., \& KarimiAllvar, N. (2007).The interrelationships of demographics, personality structure, burnout, and teacher self-efficacy among Iranian language educators. Paper presented at the forth conference on issues in language teaching in Iran. Tehran: Tehran University.

Anderson, M. B., \& Iwanicki, E. F. (1984).Teacher motivation and its relationship to teacher burnout. Educational Administration Quarterly, 20, 94-91. http://dx.doi.org/10.1177/0013161X84020002007

Bayani, A. A., Bagheri, H., \& Bayani, A. (2013). Influence of gender, age, and years of teaching experience on burnout. Scholars Research Library, 4(4), 239-243.

Bayram, N., Gürsakal, S., \& Bilgel, N. (2010).Burnout, vigor and job satisfaction among academic staff.European Journal of Social Sciences, 17(1), 41-53.

Bibou-Nakou, I., Stogiannidou, A., \& Kiosseoglou, G. (1999).The relation between teacher burnout and teachers' attributions and practices regarding school behaviour problems. School Psychology International, 20, 209-217. http://dx.doi.org/10.1177/0143034399020002004

Brissie, J. S., Hoover-Dempsey, K. V., \& Bassler, O. C. (1988).Individual, situational contributors to teacher burnout. Journal of Educational Research, 82(2), 106-112.

Burke, R. J., \& Greenglass, E. (1993). Work stress, role conflict, social support and psychological burnout among teachers. Psychological Reports, 73(2), 371-380. http://dx.doi.org/10.2466/pr0.1993.73.2.371

Burke, R. J., \& Greenglass, E. (1995).A longitudinal study of psychological burnout in teacher. Human Relations, 48(2), 187-202. http://dx.doi.org/10.1177/001872679504800205

Burke, R. J., \& Greenglass, E. R. (1989).Sex differences in psychological burnout in teachers. Psychological 
Rostami, S., Ghanizadeh, A., \& Ghapanchi, Z.

Reports, 65, 55-56. http://dx.doi.org/10.2466/pr0.1989.65.1.55

Byrne, B. M. (1991). Burnout: Investigating the impact of background variables for elementary, intermediate, secondary and university educators. Teaching and Teacher Education, 7(2), 197- 209.

http://dx.doi.org/10.1016/0742-051X(91)90027-M

Byrne, J. J. (1998). Teacher as hunger artist: Burnout: Its causes, effects and remedies. Contemporary Education, 69(2), 86-91.

Chang, M. (2009). An appraisal perspective of teacher burnout: Examining the emotional work of teachers. Educational Psychological Review, 21, 193-218. http://dx.doi.org/10.1007/s10648-009-9106-y

Diefendorff, J. M, Richard, E. M, \&Yang, J. (2008). Emotion regulation at work: Linking strategies to affective events and discrete negative emotions. Journal of Vocational Behavior, 73, 498-508. http://dx.doi.org/10.1016/j.jvb.2008.09.006

Duatepe, A., \& Akkus-cikla, O. (2004).The relationship between primary school teachers' burnout and some of their demographic variables. Pedagogika, 70, 55-60.

Egyed, C. J., \& Short, R. J. (2006).Teacher self-efficacy, burnout, experience, and decision to refer a disruptive student.School Psychology International, 27, 462-474. http://dx.doi.org/10.1177/0143034306070432

Evers, W. J. E., Brouwers, A., \& Tomic, W. (2002). Burnout and self-efficacy: a study on teachers' beliefs when implementing an innovative educational system in the Netherlands. British Journal of Educational Psychology, 72, 227-243. http://dx.doi.org/10.1348/000709902158865

Farber, B. A. (1984). Stress and burnout in suburban teachers. Journal of Educational Research, 77, 325-331.

Ghaffarzadeh Hassankiadeh, M. (2013). Schools vs. institutes in learning a foreign language: For Iranian EFL learners. International Journal of Language and Linguistics, 1(1), 40-47. http://dx.doi.org/10.11648/j.ijll.s.20130101.17

Ghanizadeh, A. (2013).A tripartite model of Iranian EFL teachers' attributions, burnout, self-regulation, and goal-orientation: Toward the prospects of effective teaching. PhD Dissertation. Ferdowsi University of Mashhad, Iran.

Ghanizadeh, A., \& Ghonsooly, B. (2014). A tripartite model of EFL teacher attributions, burnout, and self-regulation: Toward the prospects of effective teaching. Educational Research for Policy and Practice, 13(2), 145-166. http://dx.doi.org/10.1007/s10671-013-9155-3

Ghanizadeh, A., \& Jahedizadeh, S. (2014). Teacher burnout: A review of sources and ramifications. British Journal of Education, Society and Behavioural Science, 6(1), 24-39. http://dx.doi.org/10.9734/BJESBS/2015/15162

Gold, Y., \& Bachelor, P. (1988). Signs of burnout are evident for practice teachers during the teacher training period. Education, 108(4), 546-555.

Greenglass, E. R., \& Burke, R. J. (1988). Work and family precursors of burnout in teachers: Sex differences. Sex Roles, 18, 215-229. http://dx.doi.org/10.1007/BF00287791

Greenglass, E. R., \& Burke, R. J. (1990).A gender-role perspective of coping and burnout. Applied Psychology: An International Review, 39, 5- 27. http://dx.doi.org/10.1111/j.1464-0597.1990.tb01035.x

Hakanen, J. J., Bakker, A. B., \& Schaufeli, W. B. (2006).Burnout and work engagement among teachers. Journal of School Psychology, 43(6), 495-513. http://dx.doi.org/10.1016/j.jsp.2005.11.001

Harrison, B. J. (1999). Are you destined to burn out? Fund Raising Management, 30(3), 25-27.

Hastings, R. P., \& Bham, M. S. (2003). The relationship between student behavior patterns and teacher burnout. School Psychology International, 24(1), 115-127. http://dx.doi.org/10.1177/0143034303024001905

Jackson, R. A., Barnett, C. W., Stajich, G. V., \& Murphy, J. E.(1993). An analysis of burnout among school of pharmacy faculty. American Journal of Pharmaceutical Education, 57(1), 9-17.

Jacobsson, C., Pousette, A., \& Thylefors, I. (2001).Managing stress and feelings of mastery among Swedish comprehensive school teachers. Scandinavian Journal of Educational Research, 45(1), 37-53. http://dx.doi.org/10.1080/00313830020023384

Kahn, J. H., Schneider, K. T., Jenkins-Henkelman, T. M., \& Moyle, L. L. (2006). Emotional social support and job burnout among high-school teachers: Is it all due to dispositional affectivity? Journal of Organizational Behavior, 27, 793-807. http://dx.doi.org/10.1002/job.397 
A study of contextual precursors of burnout among EFL teachers

Keihaniyan, M. (2011). Teaching methodology and motivation: Comparison of Iranian English private institute and high school. Journal of Language Teaching and Research, 2(3), 588-599. http://dx.doi.org/10.4304/jltr.2.3.588-599

Lau, P. S. Y., Yuen, M. T., \& Chan, R. M. C. (2005). Do demographic characteristics make a difference to burnout among Hong Kong secondary school teachers? Social Indicators Journal, 71, 491-516. http://dx.doi.org/10.1007/s11205-004-8033-z

Maslach, C. (1982). Burnout: The cost of caring. Englewood Cliffs, NJ: Prentice-Hall.

Maslach, C., \& Jackson, S. E. (1986). Maslach burnout inventory manual (2nd ed.).Palo Alto, CA: Consulting Psychologists Press.

Maslach, C., \& Leiter, M. P. (1997).The truth about burnout: How organizations cause personal stress and what to do about it. San Francisco: Jossey-Bass.

Maslach, C., \& Leiter, M. P. (1999). Take this job and ... love it!. Psychology Today, 32(5), 50-53.

Maslach, C., Jackson, S. E., \& Leiter, M. P. (1996). Maslach burnout inventory manual (3rd ed.). Palo Alto: Consulting Psychologists Press.

Maslach, C., Schaufeli, W. B., \& Leiter, M. P. (2001).Job burnout. Annual Review of Psychology, 52(1), $397-422$. http://dx.doi.org/10.1146/annurev.psych.52.1.397

McGuire, W. H. (1979). Teacher burnout. Today's Education, 68(4), 5-7.

Milstein, M. M., Golaszewski, T. J., \& Duquette, R. D. (1984). Organizationally based stress: What bothers teachers. Journal of Educational Research, 77, 293-297.

Moazzam, I., \& Jodai, H. (2014).Characteristics of Iranian EFL teachers of high school and language institutes. International Journal of Language Learning and Applied Linguistics World, 6(4), 308-316.

Ogus, E. D., Greenglass, E. R., \& Burke, R. J. (1990). Gender-role differences, work stress and depersonalization. Journal of Social Behavior and Personality, 5,387-398.

Ozdemir, Y. (2007). The role of classroom management efficacy in predicting teacher burnout. International Journal of Social Sciences, 2(4), 257-263.

Papathanasiou, M., \& Hirsch, K. (1997).Burnout, health, and demographic variables in Greek mental health professionals. Unpublished MS dissertation, University of Wales: Cardiff.

Rashidzadeh, M. A. (2002). Burnout among Iranian school principals. Psychological Reports, 90(1), 61-64. http://dx.doi.org/10.2466/pr0.2002.90.1.61

Rosenblatt, Z. (2001). Teachers' multiple roles and skill flexibility: Effects on work attitudes. Educational Administration Quarterly, 37(5), 684-708. http://dx.doi.org/10.1177/00131610121969479

Rostami, S., Akbari, O., \& Ghanizadeh, A. (2015). The effect of smart school programs on EFL reading comprehension in an academic context. International Journal of Research Studies in Educational Technology, 4(1). http://dx.doi.org/10.5861/ijrset.2014.936

Russell, D. W., Altmaier, E., \& Van Velzen, D. (1987). Job-related stress, social support and burnout among classroom teachers. Journal of Applied Psychology, 72, 269-274. http://dx.doi.org/10.1037/0021-9010.72.2.269

Sarros, J. C., \& Sarros, A. M. (1992).Social support and teacher Burnout. Journal of Educational Administration, 30(1), 55-69. http://dx.doi.org/10.1108/09578239210008826

Schwab, R. L. (1986). Burnout in education. In C. Maslach \& S. E. Jackson, Maslach (Eds.), Burnout Inventory manual, (pp. 18-22). Palo Alto, CA: Consulting Psychologists Press.

Schwab, R. L., \& Iwanicki, E. F. (1982). Who are our burned out teachers? Educational Research Quarterly, 7 , 5- 16.

Schwab, R. L., Jackson, S. E., \& Schuler, R. A. (1986). Educator burnout: Sources and consequences. Educational Research Journal, 20(3), 14- 30.

Sunbul, A. M. (2003). An analysis of relations among locus of control, burnout and job satisfaction in Turkish high school teachers. Australian Journal of Education-Hawthorn, 47(1), 58-72. http://dx.doi.org/10.1177/000494410304700105

TabatabaeeYazdi, M., Motallebzadeh, Kh., \& Ashraf H. (2013). Iranian EFL teachers' self-efficacy and teachers' burnout: A case of comparison. International Journal of Language Learning and Applied Linguistics 
Rostami, S., Ghanizadeh, A., \& Ghapanchi, Z.

World, 4(2), 59-73.

Toker, B. (2011).Burnout among university academicians: An empirical study on the universities of Turkey.

Doğus University Journal, 12, 114-127.

Vaezi, S., \& Fallah, N. (2011).The relationship between self-efficacy and stress among Iranian EFL teachers.Journal of Language Teaching and Research, 5(2), 1168-1174.

Whitehead, A., Ryba, K., \& O’Driscoll, M. (2000).Burnout among New Zealand primary school teachers. New Zealand Journal of Psychology, 29(2), 52-60.

Zabel, R. H., \& Zabel, M. K. (2001). Revisiting burnout among special education teachers: Do age, experience, and preparation still matter? Teacher Education and Special Education, 24(2), 128-139.

http://dx.doi.org/10.1177/088840640102400207 